Іваць-Чабіна А.P.

\title{
Вивчення рівня теоретичної і практичної підготовки лікарів загальної практики - сімейних лікарів, як спеціалістів базового рівня надання медичної допомоги для забезпечення комплексної реабілітації цільових груп прикріпленого населення
}

\author{
ДВНЗ «Ужгородський національний університет», факультет здоров’я та фізичного виховання, \\ кафедра наук про здоров'я, м. Ужгород, Україна \\ anna.ivats-chabina@uzhnu.edu.ua
}

\author{
Иваць-Чабина А.P. \\ Изучение уровня теоретической и практической \\ подготовки врачей общей практики-семейных врачей \\ как специалистов базового уровня оказания \\ медицинской помощи для обеспечения комплексной \\ реабилитации целевых групп \\ прикрепленного населения \\ ГВУЗ «Ужгородский национальный университет», \\ факультет здоровья и физического воспитания, \\ кафедра наук о здоровье, г. Ужгород, Украина
}

Ivats-Chabina A.R.

Studying the level of theoretical and practical skills of general practitioners family doctors as specialists of the primary medical care for providing complex rehabilitation of target groups of the attached population SU "Uzhhorod National University", Faculty of health and physical education, Department of health sciences, Uzhhorod, Ukraine

\section{Вступ}

За визначенням ВООЗ, реабілітація - це комплексне та скоординоване використання медичних, соціальних, освітніх та професійних заходів для тренування або перепідготовки неповноспроможної особи для досягнення та підтримання найвищого можливого рівня функціонування [2,5,7].

Реабілітація є невід'ємним компонентом медичних послуг, який гарантує, що людина після перенесеного захворювання зможе повністю реалізувати свій функціональний потенціал в умовах, в яких вона живе і працює.

Згідно з Алма-Атинською декларацією 1987 року, первинна ланка медичної допомоги $\epsilon$ основним інструментом для вирішення завдання досягнення «здоров'я для всіх» i фундаментом всієї системи медичного обслуговування, а центральною фігурою первинної ланки - лікаря загальної практики - сімейного лікаря [4,6].

Історично склалося так, що реабілітація мала низький пріоритет в країнах з обмеженими інвестиціями в охорону здоров'я, що призвело до недостатньо розвиненої, погано скоординованої системи реабілітаційної допомоги $[1,3]$. На сьогоднішній день, найбільшого розвитку система реабілітації в Україні набула на санаторному етапі лікування і в закладах охорони здоров'я третинного рівня. В такій ситуації виникають труднощі із доступом до реабілітаційних послуг у тих груп населення, які їх потребують.

Часто висока вартість послуг в реабілітаційних центрах та їх географічна віддаленість, змушують пацієнтів відмовлятись від реабілітації після виписки зі стаціонару, що суттєво знижує шанси на повне відновлення функціонування та гальмує процес одужання.

Мета дослідження: вивчити рівень теоретичної та практичної підготовки лікарів загальної практики сімейних лікарів, як спеціалістів базового рівня надання медичної допомоги до забезпечення комплексної реабілітації цільових груп прикріпленого населення.

\section{Матеріали та методи}

В опитуванні, за спеціально розробленою анкетою, взяло участь 50 лікарів загальної практики - сімейних лікарів. В ході статистичної обробки 4 анкети було виключено через помилки у заповненні. Всі респонденти практикуючі лікарі.

Загальний стаж роботи лікарем у 50\% опитаних складає більше 20 років, 2,2\% працюють лікарем протягом 15-19 років, 10,9\% - 10-14 років, 6,5\% - від 6 до 9 років, $13 \%$ мають загальний стаж від 3 до 5 років та $17,4 \%-$ до 2-х років.

В якості підготовки до роботи сімейним лікарем $58,7 \%$ опитаних пройшли спеціалізацію, 41,3\% інтернатуру з сімейної медицини. 


\section{Результати дослідження та їх обговорення}

Інтеграцію на первинний рівень заходів медичної реабілітації сімейними лікарями вважають 52,2\% опитаних. Проти цього висловились 28,8\% респондентів. Не змогли визначитись $19,6 \%$.

Призначення засобів медичної реабілітації в разі потреби: 60,9\% сімейних лікарів, що брали участь в опитуванні, зазначили, що в разі потреби призначають своїм пацієнтам засоби медичної реабілітації, не призначають - 15,2\%. Не змогли визначитись з відповіддю $23,9 \%$ опитаних.

Що стосується можливості призначення всім пацієнтам засобів медичної реабілітації, розподіл був наступним: 43,5\% респондентів відповіли, що мають таку можливість. Іще $32,6 \%$ повідомили, що в разі потреби не мають змоги призначати пацієнтам заходи медичної реабілітації. Не змогли визначитись 3 відповіддю 23,9\%.

Необхідною умовою вибору оптимального методу реабілітації є контакт сімейного лікаря 3 лікарями інших спеціальностей та можливість проведення додаткових методів обстеження пацієнта. 39,1\% опитаних повідомили, що мають труднощі стосовно отримання консультацій для проведення заходів 3 медичної реабілітації пацієнтам у інших лікарів-спеціалістів. 30,4\% відповіли, що подібні труднощі виникають у них в переважній більшості випадків. У 15,2\% респондентів здебільшого не виникало проблем з отриманням консультацій від інших спеціалістів. Зовсім не виникало подібної проблеми у 13,0\% опитаних, а іще 1,2\% не змогли визначитись 3 відповіддю.

Найвищий рівень теоретичної підготовки респондентів відзначено при наступних станах: хвороби органів травлення, хвороби органів дихання, хвороби системи кровообігу.

Найнижчий рівень теоретичної підготовки сімейні лікарі мають 3 питань реабілітації інвалідів, людей похилого віку та пацієнтів після перенесених хірургічних втручань. Дані наведені у табл. 1.

Найвищим рівнем практичної підготовки респонденти володіють в таких напрямках як реабілітація дітей, реабілітація пацієнтів 3 патологією органів дихання та органів травлення. 3 надання реабілітаційних послуг цим пацієнтам респонденти дали найвищі позитивні оцінки своїм практичним навикам.

Найнижчий рівень своєї практичної підготовки респонденти відзначили 3 таких питань, як реабілітація інвалідів, пацієнтів 3 хворобами центральної нервової системи та травмами опорно-рухового апарату. Переважна більшість респондентів оцінила свій рівень практичної підготовки із організації реабілітаційної підготовки вказаним пацієнтам як більше недостатній та недостатній (табл. 2).

\section{Таблиця 1. Рівень теоретичної підготовки лікарів загальної практики - сімейних лікарів} до надання реабілітаційної допомоги, \%

\begin{tabular}{|c|c|c|c|c|c|c|}
\hline Нозології & 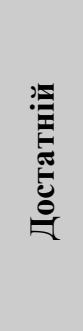 & 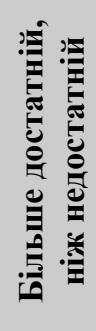 & 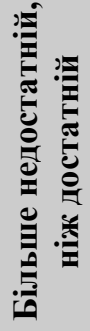 & 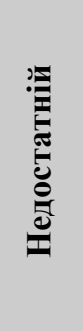 & 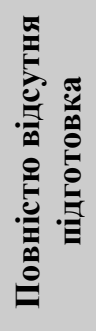 & 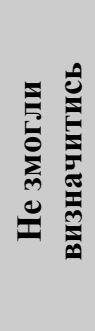 \\
\hline В цілому & 26,1 & 19,6 & 21,7 & 26,1 & 6,5 & - \\
\hline Хвороби периферичної нервової системи & 21,7 & 21,7 & 28,3 & 21,6 & 6,5 & - \\
\hline Хвороби центральної нервової системи & 21,7 & 23,9 & 19,6 & 23,9 & 6,5 & 4,3 \\
\hline Хвороби системи кровообігу & 28,3 & 34,8 & 15,2 & 13,0 & - & 4,3 \\
\hline Хвороби органів дихання & 32,6 & 28,3 & 21,7 & 10,9 & 2,2 & 4,3 \\
\hline Хвороби органів травлення & 39,1 & 23,9 & 19,6 & 13,0 & 4,3 & - \\
\hline Хвороби кістково-м’язової системи & 26,1 & 30,4 & 15,2 & 21,7 & 2,2 & 4,3 \\
\hline Травми опорно-рухового апарату & 19,6 & 26,1 & 26,1 & 19,6 & 4,3 & 4,3 \\
\hline $\begin{array}{l}\text { Тютюнова, алкогольна та наркотична } \\
\text { залежність }\end{array}$ & 21,7 & 15,2 & 19,6 & 23,9 & 13,0 & 6,5 \\
\hline Хірургічні втручання на різних органах & 17,4 & 15,2 & 24,4 & 32,6 & 10,9 & - \\
\hline Реабілітація дітей & 28,3 & 15,2 & 23,9 & 19,6 & 13,0 & - \\
\hline Реабілітація інвалідів & 17,4 & 15,2 & 26,1 & 30,4 & 10,9 & - \\
\hline Реабілітація людей похилого віку & 19,6 & 32,6 & 19,6 & 19,6 & 8,7 & - \\
\hline
\end{tabular}


Таблиця 2. Рівень практичної підготовки лікарів загальної практики - сімейних лікарів до надання реабілітаційної допомоги, \%

\begin{tabular}{|c|c|c|c|c|c|c|}
\hline Нозології & 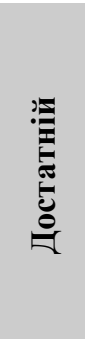 & 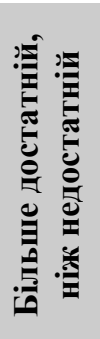 & 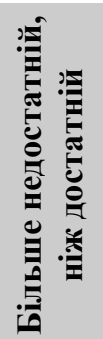 & 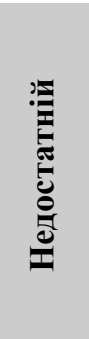 & 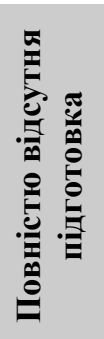 & 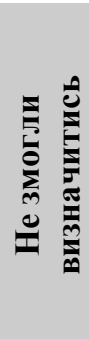 \\
\hline В цілому & 17,4 & 19,6 & 34,8 & 23.9 & - & 4,3 \\
\hline Хвороби периферичної нервової системи & 15,2 & 21,7 & 30,4 & 28,3 & 4,3 & - \\
\hline Хвороби центральної нервової системи & 15,2 & 17,4 & 28,3 & 32,6 & 6,5 & - \\
\hline Хвороби системи кровообігу & 21,7 & 26,1 & 32,6 & 13,0 & 4,3 & 2,2 \\
\hline Хвороби органів дихання & 23,9 & 28,3 & 23,9 & 15,2 & 2,2 & 4,3 \\
\hline Хвороби органів травлення & 23,9 & 30,4 & 21,7 & 15,2 & 4,3 & 4,3 \\
\hline Хвороби кістково-м’язової системи & 17,4 & 23,9 & 28,3 & 17,4 & 6,5 & 6,5 \\
\hline Травми опорно-рухового апарату & 15,2 & 19,6 & 34,8 & 17,4 & 4,3 & 8,7 \\
\hline $\begin{array}{l}\text { Тютюнова, алкогольна та наркотична } \\
\text { залежність }\end{array}$ & 21,7 & 13,0 & 26,1 & 24,0 & 15,2 & 2,2 \\
\hline Хірургічні втручання на різних органах & 17,4 & 13,0 & 32,6 & 23.9 & 8,7 & 4,3 \\
\hline Реабілітація дітей & 26,1 & 13,0 & 21,7 & 15,2 & 15,2 & 8,7 \\
\hline Реабілітація інвалідів & 15,2 & 17,4 & 28.3 & 21,7 & 10,9 & 6,5 \\
\hline Реабілітація людей похилого віку & 15,2 & 21,6 & 23,9 & 21,7 & 6,5 & 6,5 \\
\hline
\end{tabular}

В ході порівняння одержаних показників теоретичної та практичної підготовки було встановлено, що найвищим $\epsilon$ рівень теоретичної та практичної підготовки лікарів первинної ланки до надання реабілітаційної допомоги хворим із хворобами органів дихання, хворобами органів травної та хворобами системи кровообігу. Найнижчим $є$ рівень підготовки сімейних лікарів до надання реабілітаційної допомоги пацієнтам після перенесених хірургічних втручань та 3 травмами опорно-рухового апарату (тут респонденти дали найбільшу кількість негативних оцінок як 3 питань теоретичної, так і практичної підготовки).

Необхідно відмітити, що на думку респондентів, пацієнти 3 хворобами системи кровообігу, хворобами органів дихання та органів травлення, хворобами нервової системи та пацієнти після перенесених травм можуть бути передані для реабілітації сімейним лікарям.

Серед проблем, 3 якими стикаються лікарі при призначенні засобів медичної реабілітації, респонденти виділили наступні: спеціалістів;

труднощі в отриманні консультацій від лікарів-

- недостатній рівень матеріального забезпечення;

- нестача технічних засобів для проведення реабілітаційних заходів;

- нестача молодшого медперсоналу (зокрема медичних сестер).

Вдосконаленню системи реабілітаційної допомоги на первинному рівні в цілому, а також для підвищення рівня теоретичної та практичної підготовки сімейних лікарів, можуть сприяти такі заходи як:

- збільшення фінансування амбулаторій сімейної медицини;

- облаштування фізіотерапевтичних, масажних та кабінетів ЛФК на базі амбулаторій сімейної медицини;

- розширення можливостей для отримання сімейними лікарями консультацій лікарів-спеціалістів;

- покращення комунікації між профільними стаціонарами та амбулаторіями сімейної медицини;

- збільшення кількості тренінгів та семінарів 3 питань реабілітації для лікарів первинної ланки;

- можливість проходити підвищення кваліфікації 3 питань медичної реабілітації без відриву від роботи;

- професійне та матеріальне заохочення сімейних лікарів до розширення компетенцій 3 медичної реабілітації;

- збільшення кількості навчальних годин, присвячених тематиці медичної реабілітації, під час проходження лікарями навчання в інтернатурі та проведення курсів тематичного удосконалення.

Респондентам було запропоновано назвати спеціальності, за якими, на їх думку, можуть бути передані пацієнти для проведення медичної реабілітації сімейному лікарю. Респонденти вважають, що пацієнти 3 серцевосудинною патологією, пульмонологічні хворі, пацієнти 3 захворюваннями органів травлення, неврологічні хворі та пацієнти після перенесених травм можуть бути передані для реабілітації сімейним лікарям. 


\section{Результати дослідження та їх обговорення}

Інтеграцію на первинний рівень заходів медичної реабілітації сімейними лікарями вважають 52,2\% опитаних. Проти цього висловились 28,8\% респондентів. Не змогли визначитись $19,6 \%$.

Призначення засобів медичної реабілітації в разі потреби: 60,9\% сімейних лікарів, що брали участь в опитуванні, зазначили, що в разі потреби призначають своїм пацієнтам засоби медичної реабілітації, не призначають - 15,2\%. Не змогли визначитись з відповіддю $23,9 \%$ опитаних.

Що стосується можливості призначення всім пацієнтам засобів медичної реабілітації, розподіл був наступним: 43,5\% респондентів відповіли, що мають таку можливість. Іще $32,6 \%$ повідомили, що в разі потреби не мають змоги призначати пацієнтам заходи медичної реабілітації. Не змогли визначитись 3 відповіддю 23,9\%.

Необхідною умовою вибору оптимального методу реабілітації є контакт сімейного лікаря 3 лікарями інших спеціальностей та можливість проведення додаткових методів обстеження пацієнта. 39,1\% опитаних повідомили, що мають труднощі стосовно отримання консультацій для проведення заходів 3 медичної реабілітації пацієнтам у інших лікарів-спеціалістів. 30,4\% відповіли, що подібні труднощі виникають у них в переважній більшості випадків. У 15,2\% респондентів здебільшого не виникало проблем з отриманням консультацій від інших спеціалістів. Зовсім не виникало подібної проблеми у 13,0\% опитаних, а іще 1,2\% не змогли визначитись 3 відповіддю.

Найвищий рівень теоретичної підготовки респондентів відзначено при наступних станах: хвороби органів травлення, хвороби органів дихання, хвороби системи кровообігу.

Найнижчий рівень теоретичної підготовки сімейні лікарі мають 3 питань реабілітації інвалідів, людей похилого віку та пацієнтів після перенесених хірургічних втручань. Дані наведені у табл. 1.

Найвищим рівнем практичної підготовки респонденти володіють в таких напрямках як реабілітація дітей, реабілітація пацієнтів 3 патологією органів дихання та органів травлення. 3 надання реабілітаційних послуг цим пацієнтам респонденти дали найвищі позитивні оцінки своїм практичним навикам.

Найнижчий рівень своєї практичної підготовки респонденти відзначили 3 таких питань, як реабілітація інвалідів, пацієнтів 3 хворобами центральної нервової системи та травмами опорно-рухового апарату. Переважна більшість респондентів оцінила свій рівень практичної підготовки із організації реабілітаційної підготовки вказаним пацієнтам як більше недостатній та недостатній (табл. 2).

\section{Таблиця 1. Рівень теоретичної підготовки лікарів загальної практики - сімейних лікарів} до надання реабілітаційної допомоги, \%

\begin{tabular}{|c|c|c|c|c|c|c|}
\hline Нозології & 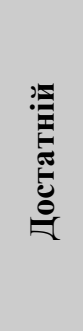 & 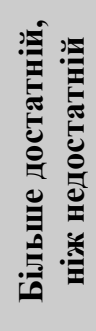 & 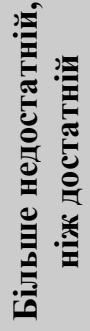 & 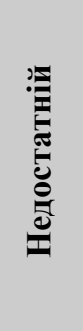 & 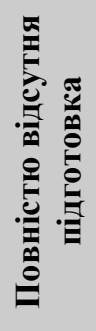 & 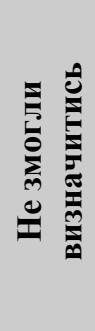 \\
\hline В цілому & 26,1 & 19,6 & 21,7 & 26,1 & 6,5 & - \\
\hline Хвороби периферичної нервової системи & 21,7 & 21,7 & 28,3 & 21,6 & 6,5 & - \\
\hline Хвороби центральної нервової системи & 21,7 & 23,9 & 19,6 & 23,9 & 6,5 & 4,3 \\
\hline Хвороби системи кровообігу & 28,3 & 34,8 & 15,2 & 13,0 & - & 4,3 \\
\hline Хвороби органів дихання & 32,6 & 28,3 & 21,7 & 10,9 & 2,2 & 4,3 \\
\hline Хвороби органів травлення & 39,1 & 23,9 & 19,6 & 13,0 & 4,3 & - \\
\hline Хвороби кістково-м’язової системи & 26,1 & 30,4 & 15,2 & 21,7 & 2,2 & 4,3 \\
\hline Травми опорно-рухового апарату & 19,6 & 26,1 & 26,1 & 19,6 & 4,3 & 4,3 \\
\hline $\begin{array}{l}\text { Тютюнова, алкогольна та наркотична } \\
\text { залежність }\end{array}$ & 21,7 & 15,2 & 19,6 & 23,9 & 13,0 & 6,5 \\
\hline Хірургічні втручання на різних органах & 17,4 & 15,2 & 24,4 & 32,6 & 10,9 & - \\
\hline Реабілітація дітей & 28,3 & 15,2 & 23,9 & 19,6 & 13,0 & - \\
\hline Реабілітація інвалідів & 17,4 & 15,2 & 26,1 & 30,4 & 10,9 & - \\
\hline Реабілітація людей похилого віку & 19,6 & 32,6 & 19,6 & 19,6 & 8,7 & - \\
\hline
\end{tabular}


Таблиця 2. Рівень практичної підготовки лікарів загальної практики - сімейних лікарів до надання реабілітаційної допомоги, \%

\begin{tabular}{|c|c|c|c|c|c|c|}
\hline Нозології & 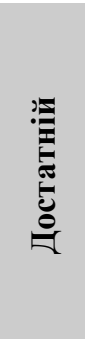 & 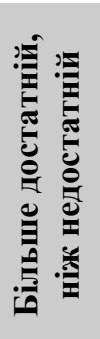 & 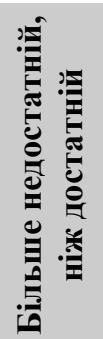 & 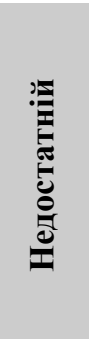 & 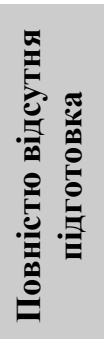 & 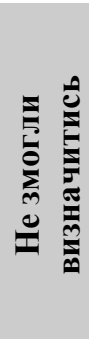 \\
\hline В цілому & 17,4 & 19,6 & 34,8 & 23.9 & - & 4,3 \\
\hline Хвороби периферичної нервової системи & 15,2 & 21,7 & 30,4 & 28,3 & 4,3 & - \\
\hline Хвороби центральної нервової системи & 15,2 & 17,4 & 28,3 & 32,6 & 6,5 & - \\
\hline Хвороби системи кровообігу & 21,7 & 26,1 & 32,6 & 13,0 & 4,3 & 2,2 \\
\hline Хвороби органів дихання & 23,9 & 28,3 & 23,9 & 15,2 & 2,2 & 4,3 \\
\hline Хвороби органів травлення & 23,9 & 30,4 & 21,7 & 15,2 & 4,3 & 4,3 \\
\hline Хвороби кістково-м’язової системи & 17,4 & 23,9 & 28,3 & 17,4 & 6,5 & 6,5 \\
\hline Травми опорно-рухового апарату & 15,2 & 19,6 & 34,8 & 17,4 & 4,3 & 8,7 \\
\hline $\begin{array}{l}\text { Тютюнова, алкогольна та наркотична } \\
\text { залежність }\end{array}$ & 21,7 & 13,0 & 26,1 & 24,0 & 15,2 & 2,2 \\
\hline Хірургічні втручання на різних органах & 17,4 & 13,0 & 32,6 & 23.9 & 8,7 & 4,3 \\
\hline Реабілітація дітей & 26,1 & 13,0 & 21,7 & 15,2 & 15,2 & 8,7 \\
\hline Реабілітація інвалідів & 15,2 & 17,4 & 28.3 & 21,7 & 10,9 & 6,5 \\
\hline Реабілітація людей похилого віку & 15,2 & 21,6 & 23,9 & 21,7 & 6,5 & 6,5 \\
\hline
\end{tabular}

В ході порівняння одержаних показників теоретичної та практичної підготовки було встановлено, що найвищим $\epsilon$ рівень теоретичної та практичної підготовки лікарів первинної ланки до надання реабілітаційної допомоги хворим із хворобами органів дихання, хворобами органів травної та хворобами системи кровообігу. Найнижчим $є$ рівень підготовки сімейних лікарів до надання реабілітаційної допомоги пацієнтам після перенесених хірургічних втручань та 3 травмами опорно-рухового апарату (тут респонденти дали найбільшу кількість негативних оцінок як 3 питань теоретичної, так і практичної підготовки).

Необхідно відмітити, що на думку респондентів, пацієнти 3 хворобами системи кровообігу, хворобами органів дихання та органів травлення, хворобами нервової системи та пацієнти після перенесених травм можуть бути передані для реабілітації сімейним лікарям.

Серед проблем, 3 якими стикаються лікарі при призначенні засобів медичної реабілітації, респонденти виділили наступні: спеціалістів;

труднощі в отриманні консультацій від лікарів-

- недостатній рівень матеріального забезпечення;

- нестача технічних засобів для проведення реабілітаційних заходів;

- нестача молодшого медперсоналу (зокрема медичних сестер).

Вдосконаленню системи реабілітаційної допомоги на первинному рівні в цілому, а також для підвищення рівня теоретичної та практичної підготовки сімейних лікарів, можуть сприяти такі заходи як:

- збільшення фінансування амбулаторій сімейної медицини;

- облаштування фізіотерапевтичних, масажних та кабінетів ЛФК на базі амбулаторій сімейної медицини;

- розширення можливостей для отримання сімейними лікарями консультацій лікарів-спеціалістів;

- покращення комунікації між профільними стаціонарами та амбулаторіями сімейної медицини;

- збільшення кількості тренінгів та семінарів 3 питань реабілітації для лікарів первинної ланки;

- можливість проходити підвищення кваліфікації 3 питань медичної реабілітації без відриву від роботи;

- професійне та матеріальне заохочення сімейних лікарів до розширення компетенцій 3 медичної реабілітації;

- збільшення кількості навчальних годин, присвячених тематиці медичної реабілітації, під час проходження лікарями навчання в інтернатурі та проведення курсів тематичного удосконалення.

Респондентам було запропоновано назвати спеціальності, за якими, на їх думку, можуть бути передані пацієнти для проведення медичної реабілітації сімейному лікарю. Респонденти вважають, що пацієнти 3 серцевосудинною патологією, пульмонологічні хворі, пацієнти 3 захворюваннями органів травлення, неврологічні хворі та пацієнти після перенесених травм можуть бути передані для реабілітації сімейним лікарям. 
Також учасникам опитування було запропоновано оцінити відповідність матеріально-технічної бази їх амбулаторій умовам проведення реабілітаційних заходів. 78,3\% вважають, що амбулаторії сімейної медицини не володіють необхідними умовами. 8,7\% вважають, що сімейна амбулаторія, в якій вони працюють, має необхідне матеріально-технічним забезпечення для проведення медичної реабілітації. 13,0\% не змогли визначитися 3 відповіддю на дане запитання

Перспективи подальших досліджень пов'язані з вивченням обсягів надання реабілітаційних послуг на первинному рівні надання медичної допомоги.

\section{Висновки}

Найвищим $€$ рівень теоретичної та практичної підготовки лікарів первинної ланки до надання реабілітаційної допомоги хворим із хворобами органів дихання та органів травлення, хворобами системи кровообігу.

Найнижчий рівень підготовки встановлено до надання реабілітаційних послуг хворим після перенесених хірургічних втручань та 3 травмами опорно-рухового апарату (тут респонденти дали найбільшу кількість негативних оцінок як 3 питань теоретичної, так і практичної підготовки).

Водночас переважна більшість опитаних висловили бажання використовувати методи медичної реабілітації у своїй практиці. Також на думку респондентів, пацієнти 3 хворобами системи кровообігу, хворобами органів дихання та органів травлення, хворобами нервової системи та пацієнти після перенесених травм можуть бути передані для реабілітації сімейним лікарям.

Загалом встановлено, що рівень підготовки лікарів первинної ланки $€$ недостатнім для надання реабілітаційних послуг на базі закладів первинної медикосанітарної допомоги і потребує розширення компетенцій сімейних лікарів $з$ даного напрямку їх діяльності.

\section{Література}

1. People-centred and integrated health services: an overview of the evidence: interim report [Internet]. World Health Organization; 2015 p. 7-11. Available from: https://apps.who.int/iris/handle/10665/155004.

2. Guidelines on Health-Related Rehabilitation (Rehabilitation Guidelines) [Internet]. World Health Organization; 2012. Available from: https://www.who.int/disabilities/care/rehabilitation_guidelines_concept.pdf.

3. Wilson RD, Lewis SA, Murray PK. Trends in the rehabilitation therapist workforce in underserved areas: 1980-2000. The Journal of Rural Health: official journal of the American Rural Health Association and the National Rural Health Care Association. 01 Jan, 2009;25(1):26-32.

4. Rehabilitation in health systems [Internet]. World Health Organization ; 2017. Available from: https://apps.who.int/ iris/bitstream/handle/10665/254506/9789241549974-eng.pdf?sequence=8.

5. Дементьева Н.Ф., Сырникова Б. А., Ларионова В. С. Медицинская реабилитация инвалидов и сущность медикооздоровительного маршрута. Медико-социальная экспертиза и реабилитация. 2005;2:53-56.

6. Матюха Л.Ф., Гойда Н.І., Слабкий В.Г., Олійник М.В. Науково обгрунтовані підходи до кваліфікаційної характеристики лікаря загальної практики - сімейного лікаря з позиції компетентісного підходу. Методичні рекомендації. . Київ: НМАПО ім. П. Л. Шупика, ДУ «Український інститут стратегічних досліджень МОЗ України»; 2010. 27 с.

7. Самоходський В. М. Наш варіант реформування охорони здоров'я на регіональному рівні. Вісник соціальної гігієни та організації охорони здоров’я України. 2016;2:81-85.

\section{References}

1. People-centred and integrated health services: an overview of the evidence: interim report [Internet]. World Health Organization; 2015 p. 7-11. Available from: https://apps.who.int/iris/handle/10665/155004.

2. Guidelines on Health-Related Rehabilitation (Rehabilitation Guidelines) [Internet]. World Health Organization; 2012. Available from: https://www.who.int/disabilities/care/rehabilitation_guidelines_concept.pdf.

3. Wilson RD, Lewis SA, Murray PK. Trends in the rehabilitation therapist workforce in underserved areas: 1980-2000. The Journal of Rural Health: official journal of the American Rural Health Association and the National Rural Health Care Association. 01 Jan, 2009;25(1):26-32.

4. Rehabilitation in health systems [Internet]. World Health Organization ; 2017. Available from: https://apps.who.int/ iris/bitstream/handle/10665/254506/9789241549974-eng.pdf?sequence=8.

5. Dementeva N.F., Syrnikova B. A., Larionova V. S. Medicinskaya reabilitaciya invalidov i sushnost medikoozdorovitelnogo marshruta . Mediko-socialnaya ekspertiza i reabilitaciya. 2005;2:53-56.

6. Matyuha L.F., Gojda N.I., Slabkij V.G., Olijnik M.V. Naukovo obgruntovani pidhodi do kvalifikacijnoyi harakteristiki likarya zagalnoyi praktiki - simejnogo likarya z poziciyi kompetentisnogo pidhodu. Metodichni rekomendaciyi. . Kiyiv: NMAPO im. P. L. Shupika, DU «Ukrayinskij institut strategichnih doslidzhen MOZ Ukrayini»; 2010. 27 s.

7. Samohodskij V. M. Nash variant reformuvannya ohoroni zdorov'ya na regionalnomu rivni. Visnik socialnoyi gigiyeni ta organizaciyi ohoroni zdorov'ya Ukrayini. 2016;2:81-5.

Дата надходження рукопису до редакції: 06.08.2019 р. 
Мета дослідження: вивчити рівень теоретичної та практичної підготовки лікарів загальної практики-сімейних лікарів, як спеціалістів базового рівня надання медичної допомоги до забезпечення комплексної реабілітації цільових груп прикріпленого населення.

Матеріали та методи. В опитуванні, за спеціально розробленою анкетою, взяло участь 50 лікарів загальної практики - сімейних лікарів. Всі респонденти - практикуючі лікарі. Запитання стосувались готовності лікарів загальної практики до надання послуг з медичної реабілітації, рівня їх теоретичної та практичної підготовки для надання реабілітаційної допомоги пацієнтам 3 різними нозологіями, пропозицій що до заохочення лікарів надавати реабілітаційну допомогу цільовим групам населення та можливість підвищення їх кваліфікації в даній галузі.

Висновки. Найвищим є рівень теоретичної та практичної підготовки лікарів первинної ланки до надання реабілітаційної допомоги хворим із хворобами органів дихання, органів травлення та хворобами системи кровообігу.

Найнижчим рівень підготовки в таких напрямках, як реабілітації хворих після перенесених хірургічних втручань та 3 травмами опорно-рухового апарату (тут респонденти дали найбільшу кількість негативних оцінок як 3 питань теоретичної так і практичної підготовки).

Загалом рівень підготовки лікарів первинної ланки є недостатнім для повноцінного надання реабілітаційних послуг на базі закладів ПМСД.

Ключові слова: реабілітація, медична реабілітація, первинна медико-санітарна допомога.

Цель исследования: изучить уровень теоретической и практической подготовки врачей общей практики семейных врачей, как специалистов базового уровня оказания медицинской помощи к обеспечению комплексной реабилитации целевых групп прикрепленного населения.

Материалы и методы. В опросе, по специально разработанной анкете, приняло участие 50 врачей общей практики - семейных врачей. Все респонденты являются практикующими врачами. Вопросы касались готовности врачей общей практики к оказанию услуг медицинской реабилитации, уровня их теоретической и практической подготовки для оказания реабилитационной помощи пациентам с различными нозологиям, предложений, касающихся поощрения врачей к предоставлению реабилитационной помощь целевым группам населения и возможности повышения их квалификации в данной области.

Выводы. Наивысшим уровнем теоретической и практической подготовки врачи первичного звена обладают для оказания реабилитационной помощи пациентам с заболеваниями органов дыхания, пищеварительной системы и сердечно-сосудистой системы.

Самый низкий уровень подготовки в таких отраслях как реабилитации больных после перенесенных хирургических вмешательств и с травмами опорно-двигательного аппарата (здесь респонденты дали наибольшее количество негативных оценок как по теоретической, так и практической подготовки).

В целом, по состоянию на сегодняшний день, уровень подготовки врачей первичного звена является недостаточным для полноценного оказания реабилитационных услуг на базе учреждений ПМСП.

Ключевые слова: реабилитация, медицинская реабилитация, первичная медико-санитарная помощь.

Purpose: the aim of this research was to study the level of theoretical and practical skills of general practitioners, family doctors, as specialists of primary medical care for providing complex rehabilitation for target groups of the attached population.

Materials and methods. The survey was participated by 50 primary healthcare doctors. All respondents are practitioners. For this study was developed a special questionnaire, which includes 4 blocks of questions. The questions concerned the readiness of participants to provide medical rehabilitation services, the level of their theoretical and practical skills for the provision of rehabilitation assistance for patients with various diseases, proposals for encouraging physicians to provide rehabilitation assistance to target populations and the opportunity to upgrade their skills.

Conclusions. The highest level of theoretical and practical skills of primary care doctors in providing rehabilitation care to patients with diseases of the respiratory system, digestive and cardiovascular systems.

The lowest level of skills in such disciplines as rehabilitation of patients after surgeries and injuries of the musculoskeletal system (the respondents gave the largest number of negative assessments for both theoretical and practical skills).

Therefore, at the present time, the level of practical and theoretical skills of primary care doctors is not enough for fullfledged high-quality rendering of rehabilitation services in PHC facilities.

Key words: rehabilitation, medical rehabilitation, primary health care.

\section{Відомості про автора}

Іваць-Чабіна Анна Романівна - асистент кафедри наук про здоров'я факультету здоров'я та фізичного виховання ДВНЗ «Ужгородський національний університет»; пл. Народна, 3, м. Ужгород, 88000, Україна. +380 (68) 632-03-15, anna.ivats-chabina@ uzhnu.edu.ua, ORCID 0000-0002-8280-8374. 